\title{
Characterization and Dynamic Analysis of Dissolved Proteins in Lake Biwa Using Two-Dimensional Electrophoresis
}

\author{
Etsu Yamada, ${ }^{* \dagger}$ Keisuke SaSaI, ${ }^{* *}$ Ryota Higa, ${ }^{* *}$ Hirotaka Mizuguchi, ${ }^{* *}$ and Yasuro FuSE ${ }^{* * * * *}$ \\ *Kyoto Institute of Technology, Matsugasaki, Sakyo, Kyoto 606-8585, Japan \\ **Department of Chemistry and Material Technology, Kyoto Institute of Technology, Matsugasaki, Sakyo, \\ Kyoto 606-8585, Japan \\ ***Center for Environmental Science, Kyoto Institute of Technology, Matsugasaki, Sakyo, Kyoto 606-8585, Japan
}

\begin{abstract}
Concentrated protein-like fluorophores of dissolved organic matter (DOM) in Lake Biwa were analyzed using sodium dodecyl sulfate-polyacrylamide gel electrophoresis (SDS-PAGE) and two-dimensional electrophoresis (2-DE). As a result, it was found that the protein-like fluorophores in Lake Biwa are likely to be dissolved proteins released from phytoplankton. SDS-PAGE analysis revealed that protein-like fluorophores from Lake Biwa usually consist of proteins with molecular weights of $33-35,42-45,56-59$ and $62-66 \mathrm{kDa}$. The molecular weights (MWs) and isoelectric points $(\mathrm{p} I s)$ of dissolved proteins in Lake Biwa were firstly clarified using 2-DE. The 2-DE patterns of proteins in Lake Biwa were compared with those for algal DOM released from four kinds of lake phytoplankton, Microcystis aeruginosa, Staurastrum dorsidentiferum, Cryptomonas ovata, and Fragilaria capucina. Some of the protein spots in 2-DE of Lake Biwa were similar to those of algal DOM released during cultivation. The relations between monthly changes in the electrophoretic gel images of lake water samples and those in the community structure of phytoplankton in Lake Biwa were observed. These results suggest that some of the dissolved proteins in Lake Biwa are likely derived from phytoplankton.
\end{abstract}

Keywords Protein-like fluorophores, dissolved proteins, dissolved organic matter, Lake Biwa, SDS-PAGE, two-dimensional electrophoresis, phytoplankton

(Received November 28, 2019; Accepted January 7, 2020; Advance Publication Released Online by J-STAGE January 17, 2020)

\section{Introduction}

As an annual increase in chemical oxygen demand (COD) has been observed in Lake Biwa since 1985, in contrast to the biochemical oxygen demand (BOD) values, ${ }^{1}$ it is thought that refractory organic matter may have gradually accumulated in Lake Biwa. Similar phenomena have been observed in other lakes and inner bays. ${ }^{2}$ Therefore, studies to estimate the source and cause of the increase in refractory organic matter in Lake Biwa have been carried out using chemical fractionation methods, ${ }^{3,4}$ the natural carbon stable isotope ratio, ${ }^{5,6}$ the box model, ${ }^{7}$ and so on. It has been reported that the increase in refractory DOM may be attributed to the contribution of not only humic substances from soils around the rivers flowing into Lake Biwa but also algal DOM from phytoplankton in the lake. ${ }^{3,8-14}$ Furthermore, it has been clarified that humic substances might be released regularly from lake sediment. ${ }^{15,16}$ However, few studies of the characteristics and contribution of algal DOM to refractory DOM in lake water have been carried out.

The fulvic-like fluorophores $(\mathrm{Ex} / \mathrm{Em}=320-350 / 430-450$,

$\dagger$ To whom correspondence should be addressed.

E-mail: eyamada@kit.ac.jp

H. M. present address: Environmental Safety Management Center, Uji Campus, Kyoto University, Gokasho, Uji, Kyoto 611-0011, Japan.
$240-260 / 430-450 \mathrm{~nm})$ and a protein-like fluorophore $(\mathrm{Ex} / \mathrm{Em}=$ $280-290 / 320-330 \mathrm{~nm}$ ), which are usually detected in Lake Biwa using a three-dimensional excitation-emission matrix (3-DEEM), were also observed in the cultivation from three kinds of phytoplankton, Microcystis aeruginosa, Staurastrum dorsidentiferum, and Cryptomonas ovata. ${ }^{11,12}$ As the fulvic-like fluorophores and protein-like fluorophore have similar fluorescence of the soil fulvic acid (FA) and protein (tryptophan or tyrosine), they are referred to as fulvic-like fluorophores and a protein-like fluorophore, respectively. ${ }^{11,17}$ The fulvic-like fluorophores released from these phytoplankton show similar fluorescence to that from the soil FA but exhibit mainly hydrophilic characteristics. ${ }^{11,12}$ The molecular weight of over $70 \%$ of fulvic-like fluorophores from these phytoplankton was estimated to be less than $3 \mathrm{kDa}$. Meanwhile, the molecular weight of the protein-like fluorophores released from phytoplankton was estimated to be over $10 \mathrm{kDa}$ and different depending on the algal species using sodium dodecyl sulfatepolyacrylamide gel electrophoresis (SDS-PAGE). ${ }^{18}$ These results indicate that some fulvic-like fluorophores and proteinlike fluorophores derived from phytoplankton are present in Lake Biwa because some of these fluorophores are relatively refractory. ${ }^{15}$

It has been reported that much of the DOM present in the oceans is refractory. ${ }^{19-21}$ Proteins in seawater were investigated to understand the source and transfer processes of refractory DOM. Dissolved proteins with apparent molecular weights of 34,39 , and $48 \mathrm{kDa}$ were usually detected in studies with the use 
of SDS-PAGE in marine environments. ${ }^{22-27}$ The identification of these dissolved proteins indicates that bacterial membrane proteins are an important source of dissolved protein in seawater. ${ }^{24,25}$ However, few studies on the presence of dissolved proteins in fresh water such as Lake Biwa have been carried out. In the present study, concentrated protein-like fluorophores of DOM in Lake Biwa were separated from fulvic-like fluorophores and analyzed using SDS-PAGE and two-dimensional electrophoresis (2-DE) in order to clarify their characterization and dynamics. The SDS-PAGE method developed for the analysis of protein-like fluorophores from phytoplankton ${ }^{18}$ was applied to the analysis of protein-like fluorophores in Lake Biwa. The molecular weights (MWs) and isoelectric points $(\mathrm{p} I s)$ of dissolved proteins in Lake Biwa were firstly clarified using 2-DE, and it was found that some of these proteins might be glycosylated with a variable linkage between the sugar and polypeptide chains. Furthermore, the results were compared with those for algal DOM released by phytoplankton during cultivation and the community structure of phytoplankton in Lake Biwa, and the dissolved proteins in lake water are likely derived from phytoplankton because some of the protein spots in 2-DE of Lake Biwa were similar to those of algal DOM released during cultivation.

\section{Experimental}

\section{Reagents and apparatus}

Humic and fulvic acids obtained from the A-horizons of brown forest soil (Dystric Cambisol, Dando, Aichi, Japan) were supplied by the Japan Humic Substances Society and used as a standard without further purification. Four kinds of lake phytoplankton, Microcystis aeruginosa (NIES-109, Lake Yogo, Shiga, Cyanobacteria), Staurastrum dorsidentiferum (NIES-665, Lake Biwa, Shiga, Chlorophyceae), Cryptomonas ovata (NIES275, Tsuchiura, Ibaraki, Cryptophyceae), and Fragilaria capucina (NIES-391, Lake Kasumigaura, Ibaraki, Bacillariophyceae), which were supplied by the National Institute for Environmental Studies, were cultivated in accordance with the procedures described in our previous papers ${ }^{11,12,14}$ and used. All other chemicals were of the best commercial grade available. Pure water was prepared using a Millipore Milli-Q water purification system.

The apparatus used for HPLC was the same as in our previous papers. ${ }^{11,12}$ A Shimadzu LC solution was used for data analysis. The test samples were applied to a gel filtration column, Superose HR10/30 (300 × $10 \mathrm{~mm}$ i.d.; GE Healthcare), using a sample injector (Rheodyne 7125 ) with a $100-\mu \mathrm{L}$ loop. A TOC meter (Shimadzu TOC-V CSH) was used to determine the DOC. A Kubota KN-70 centrifuge and a Hitachi Koki Himac CR20GIII refrigerated centrifuge were used for the fractionation and concentration of DOM, respectively. The fluorescence properties of DOM in Lake Biwa and the algal DOM were measured with 3-DEEM using a fluorescence spectrophotometer (Shimadzu RF-5300PC), according to the procedure described in our previous papers. ${ }^{11,12}$ The values were treated as the relative fluorescence intensity (RFI).

Analysis of the concentrated protein-like fluorophores of DOM in Lake Biwa using SDS-PAGE and gel chromatography

The water samples from Lake Biwa were collected in the northern basin, Imazu (St. 17B, North latitude $35^{\circ} 23^{\prime} 41^{\prime \prime}$, East longitude $\left.136^{\circ} 07^{\prime} 57^{\prime \prime}\right)$, every month. The phytoplankton samples (St. 17B, water depth $0-20 \mathrm{~m}$ ) were collected using a plankton net (mesh $25 \mu \mathrm{m})$ with water samples, and their cells were counted under a microscope.

A 2-3 L sample of surface water was poured through a membrane filter $(0.45 \mu \mathrm{m}$, Millipore). The filtrate was concentrated to $40-50 \mathrm{~mL}$ by freeze-drying and further concentrated to $3 \mathrm{~mL}$ using an Amicon Ultra ultrafiltration tube ([MWCO] $=10 \mathrm{kDa}$, Millipore) with centrifugation at $1.3 \mathrm{kG}$ and $4{ }^{\circ} \mathrm{C}$ (Step I). The concentrated sample solution $(3 \mathrm{~mL})$ was loaded on an Econo-Pac 10DG column (exclusion limit: $6 \mathrm{kDa}$, Bio-Rad) to exchange the buffer solution. The $3 \mathrm{~mL}$ of eluate was dumped and subsequently eluted with $4 \mathrm{~mL}$ of a Tris-HCl buffer. Four milliliters of eluate was further concentrated to $0.5-1.0 \mathrm{~mL}$ using an Amicon Ultra ultrafiltration tube ([MWCO] $=10 \mathrm{kDa}$, Millipore) with centrifugation at $1.3 \mathrm{kG}$ and $4{ }^{\circ} \mathrm{C}$ (Step II). The concentrated protein-like fluorescence DOM ( $\geq 10 \mathrm{kDa})$ was fully separated from other low-molecularweight substances.

The concentrated protein-like fluorophores in Lake Biwa were subjected to SDS-PAGE to analyze the protein-like components. The SDS-PAGE was performed in the same way as our previous paper. ${ }^{18}$ The gel was stained using silver instead of Coomassie Brilliant Blue (CBB) because silver is more sensitive than CBB. The same samples were also analyzed using gel chromatography with a fluorescence detector $(\mathrm{Ex} / \mathrm{Em}=280 / 320 \mathrm{~nm})$ and a UVVIS detector $(280 \mathrm{~nm})$. As neither the sorption nor ion exclusion of humic substances (and/or fulvic-like fluorophores) took place in elution with $0.01 \mathrm{M}$ sodium hydroxide solution, ${ }^{28}$ this solution was used as an eluent at a flow rate of $0.4 \mathrm{~mL} \mathrm{~min}^{-1}$. Here, it was confirmed that no denaturation of proteins (and/or proteinlike fluorophores) occurred if analyzed immediately after sample preparation in $0.01 \mathrm{M}$ sodium hydroxide solution.

Analysis of the concentrated protein-like fluorophores of DOM in Lake Biwa using 2-DE

A $10-20 \mathrm{~L}$ sample of lake water (St. 17B) was poured through a membrane filter $(0.45 \mu \mathrm{m}$, Millipore), and the filtrate was concentrated to about $100 \mathrm{~mL}$ by a crossflow ultrafiltration system (Vivaflow 200, Sartorius) having a filter with a normal molecular mass cutoff of $10 \mathrm{kDa}(10,000 \mathrm{NMMCO}$ filter, polyethersulfone membrane, Sartorius). The concentrated sample solution was concentrated to $3 \mathrm{~mL}$ by freeze-drying and then further concentrated to about $200 \mu \mathrm{L}$ according to the procedure of Step II.

The concentrated samples were pretreated according to the EzApply 2D Kit manual (ATTO). The reagent solutions named Solution 1, Solution 2 and Solution 2-2 in this Kit were used. ${ }^{29}$ Solution 1 (overlay solution) consists of glycerin and bromophenol blue (BPB). Solution 2 consists of Tris-HCl, urea, thiourea, amphoteric carrier, surfactant, and dithiothreitol. Solution 2-2 was prepared by dissolving powder of 2-iodoacetamide for it in $2 \mathrm{~mL}$ of pure water before use. Five microliters of Solution 2 was added to $50 \mu \mathrm{L}$ concentrated sample, and then the solution was incubated at room temperature for $10 \mathrm{~min}$. Five microliters of Solution 2-2 was further added, and the solution was incubated at room temperature for $10 \mathrm{~min}$. Fifty microliters of the electrophoretic sample was applied to an agar GEL (A-M310, pH 3 - 10, ATTO), and Solution 1 was applied. The first-dimensional electrophoresis was carried out with the horizontal electrophoresis system WSE-1500 disc Run IEF (ATTO) at $300 \mathrm{~V}$ for $210 \mathrm{~min}$. $\mathrm{NaOH}(0.2 \mathrm{M})$ and phosphoric acid $(10 \mathrm{mM})$ were used as an upper electrode solution and lower electrode solution, respectively.

The IEF gel was shaken in $2.5 \%$ trichloroacetic acid (TCA) for $3 \mathrm{~min}$, washed with pure water, and equilibrated with buffer solution (0.5 mM Tris- $\mathrm{HCl}$ (pH 6.8), 2\% SDS, and $0.001 \%$ $\mathrm{BPB})$ for $10 \mathrm{~min}$ at room temperature with shaking. Then the 


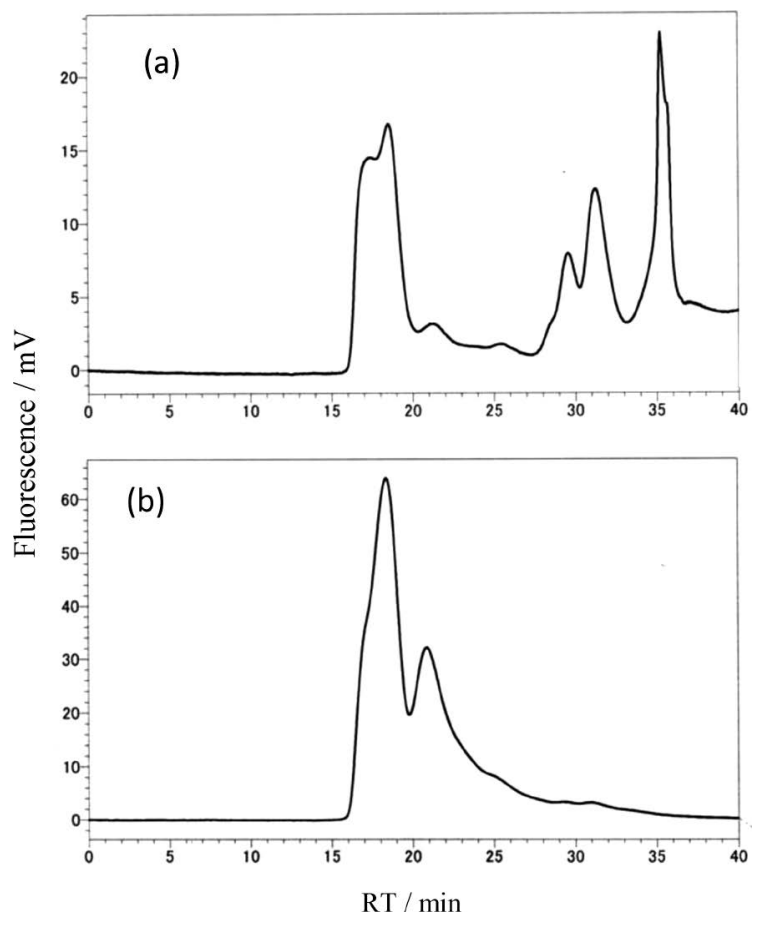

Fig. 1 Gel chromatograms of concentrated fluorophores $(\mathrm{Ex} / \mathrm{Em}=$ 280/320 nm) in the surface water of Lake Biwa (St. 17B, Sep. 2014). (a) After Step I (b) after Step I and Step II.

gel was set on the e-PAGEL (E-D 12.5 L, 12.5\% acrylamide, ATTO), and the second-dimensional electrophoresis (SDSPAGE) was performed at a constant current of $20 \mathrm{~mA}$ for 80 min. A molecular weight marker (Bio-Rad, Precision Plus Protein Standards) was also used as a standard. After electrophoresis, the proteins on the gel were visualized by the silver staining method using a silver stain MS kit (Wako Pure Chemical Corporation) and analyzed using Image J (Ver. 150i, NIH). ${ }^{30,31}$

\section{Results and Discussion}

Concentration and separation of protein-like fluorophores in Lake Biwa by freeze-drying and ultrafiltration

As the concentration of DOM in Lake Biwa is low, the concentrated DOM in the surface water (St. 17B, May 2013) was fractionated by ultrafiltration and measured using a 3-DEEM. The molecular weight of over $60 \%$ of fulvic-like fluorophores in the surface water of Lake Biwa was estimated to be less than $3 \mathrm{kDa}$. The molecular weight of protein-like fluorophores in Lake Biwa was estimated to be mainly both over $30 \mathrm{kDa}(65.2 \%)$ and less than $3 \mathrm{kDa}(26.3 \%)$. Since it is difficult to separate protein-like fluorophores less than $3 \mathrm{kDa}$ from fulvic-like fluorophores, only those over $10 \mathrm{kDa}$ were isolated and their characterization and dynamics were investigated in this paper.

The gel chromatograms of concentrated fluorophores $(\mathrm{Ex} / \mathrm{Em}$ $=280 / 320 \mathrm{~nm}$ ) after Steps I and II are shown in Fig. 1(a) and 1(b), respectively. The procedures of Steps I and II are stated in the experimental section. The filtrate of $2.4 \mathrm{~L}$ of surface water (St. 17B, September 2014) was concentrated using freezedrying and ultrafiltration (Step I). The protein-like fluorophores in Lake Biwa could be detected after Step I; their concentrations became higher, and other peaks (RT $\geq 30 \mathrm{~min}$ ), which may be

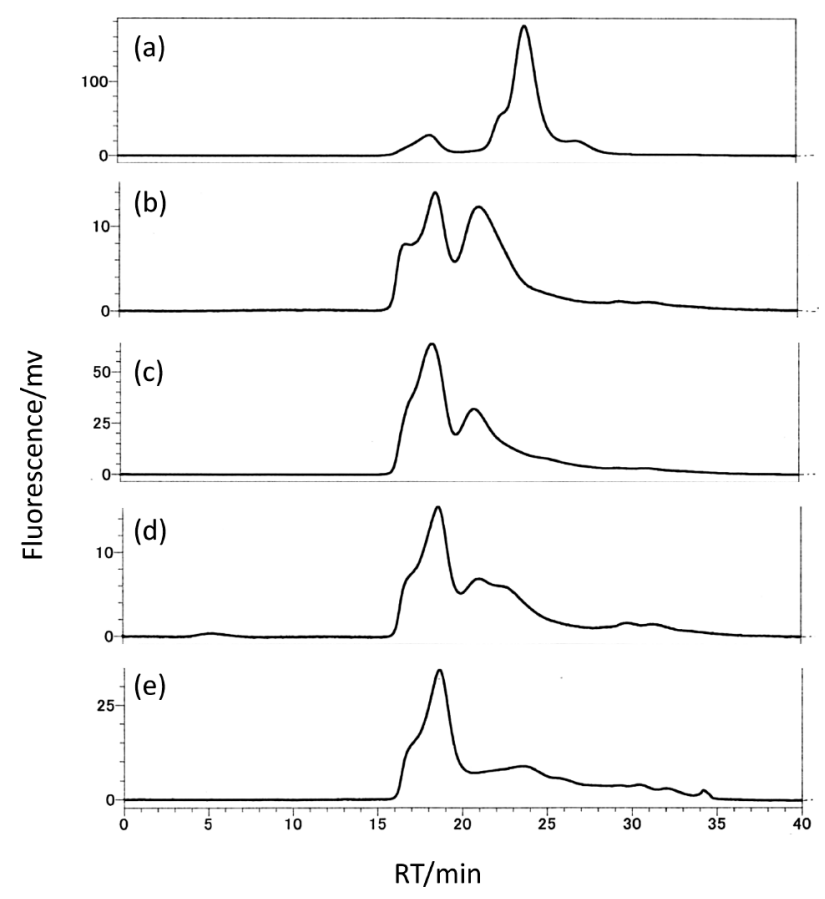

Fig. 2 Gel chromatograms of the concentrated protein-like fluorophores $(\mathrm{Ex} / \mathrm{Em}=280 / 320 \mathrm{~nm})$ in the surface water of Lake Biwa (St. 17B). (a) Nov. 2013, (b) June 2014, (c) Sep. 2014, (d) Oct. 2014, (e) Nov. 2014.

largely fulvic-like fluorophores and partly protein-like fluorophores $(\leq 3 \mathrm{kDa})$, had almost disappeared after Step II (Fig. 1(b)). These substances were removed using an EconoPac 10-DG column. Meanwhile, only protein-like fluorescence peak (Peak C) was detected using a 3-DEEM after Step II. These results indicate that only protein-like fluorophores $(\geq 10 \mathrm{kDa})$ can be separated from interfering substances such as fulvic-like fluorophores and others via these steps prior to the SDS-PAGE and 2-DE analysis.

Analysis of concentrated protein-like fluorophores in Lake Biwa using SDS-PAGE and gel chromatography

The gel chromatograms of concentrated protein-like fluorophores $(E x / E m=280 / 320 \mathrm{~nm})$ in Lake Biwa (St. 17B, water depth $0.5 \mathrm{~m})$ collected in November $2013(2.2 \mathrm{~L}$ to $1 \mathrm{~mL})$ and in June (3 $\mathrm{L}$ to $0.6 \mathrm{~mL})$, September $(2.4 \mathrm{~L}$ to $0.5 \mathrm{~mL})$, October $(2.2 \mathrm{~L}$ to $0.8 \mathrm{~mL}$ ), and November ( $2.2 \mathrm{~L}$ to $0.5 \mathrm{~mL}) 2014$ are shown in Fig. 2. Since the peak intensities of protein-like fluorophores were quite different depending on the month of sampling, the vertical axis scale in Fig. 2 is set differently for each month. Although two peaks (RT $=17-19 \mathrm{~min}$ ) and a somewhat broad peak (RT $=20-22 \mathrm{~min}$ ) were observed in lake water samples collected in June, September, and October 2014, the peak intensities of protein-like fluorophores in September 2014 were higher than those in the other two months. It is thought that similar protein-like fluorophores were present in these three months, but its concentrations were higher in September 2014 than the other two months. In the lake water sample collected in November 2013, two significant peaks (RT $=23-24 \mathrm{~min}$ ) were observed. Standard proteins (Bio-Rad, Gel Filtration standard), myoglobin (horse, $17 \mathrm{kDa}$ ), ovalbumin (chicken, $44 \mathrm{kDa}), \gamma$-globulin $(158 \mathrm{kDa})$, and thyroglobulin $(670 \mathrm{kDa})$ were measured via gel chromatography with a UV detector $(280 \mathrm{~nm})$ under the same conditions. An overlapping peak of thyroglobulin and $\gamma$-globulin, a peak of ovalbumin, and a peak 


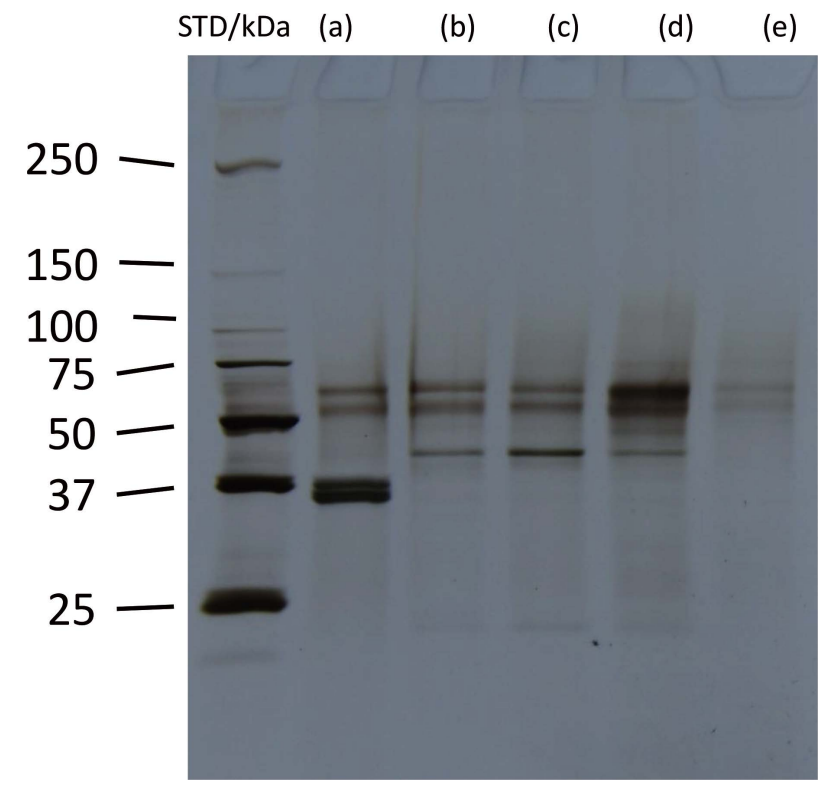

Fig. 3 SDS-PAGE analysis of the concentrated protein-like fluorophores in the surface water of Lake Biwa (St. 17B). The amount of sample loaded on the gel was equivalent to around $2 \mathrm{~L}$ of the original lake water, 2.2 L ((a) Nov. 2013), 3 L ((b) June 2014), 2.4 L ((c) Sep. 2014), 2.2 L ((d) Oct. 2014), and 2.2 L ((e) Nov. 2014). STD: marker.

Table 1 Molecular weights of protein-like fluorophores in the surface water of Lake Biwa determined by SDS-PAGE with silver stain

\begin{tabular}{cc}
\hline Sample & Molecular weight of protein/kDa \\
\hline Lake Biwa (St. 17B, water depth 0.5 m) \\
Nov. 5, 2013 & $33,35,58,66$ \\
June 2, 2014 & $43,59,66$ \\
Sept. 1, 2014 & $42,58,65$ \\
Oct. 8, 2014 & $42,49,56,63,76$ \\
Nov. 4, 2014 & $40,52,57,64,75$ \\
Dec. 1, 2014 & $31,34,45,56,63$ \\
Jan. 5, 2015 & $44,56,62$ \\
\hline
\end{tabular}

of myoglobin were detected at RT $=17-20,21-23$, and $23-$ $25 \mathrm{~min}$, respectively. From the results of standard proteins, the peaks of protein-like fluorophores at RT $=17-19,20-22$, and 23 - 24 min were estimated to be over $50 \mathrm{kDa}$, approximately 44 , and $30-40 \mathrm{kDa}$, respectively.

The SDS-PAGE patterns of concentrated protein-like fluorophores in the same water samples of Lake Biwa (St. 17B, water depth $0.5 \mathrm{~m}$ ) collected in November 2013 and in June, September, October, and November 2014 are shown in Fig. 3. The SDSPAGE results were analyzed using NIH ImageJ (Ver. 1.50i) ${ }^{30,31}$ and the analytical results are listed in Table 1. The results for December 2014 and January 2015 are also shown in Table 1. The bands with molecular weights of $56-59$ and $62-66 \mathrm{kDa}$ were detected in all water samples from Lake Biwa. The clear band at $33-35 \mathrm{kDa}$ was observed only in the lake water sample collected in November 2013, and the bands at $42-45 \mathrm{kDa}$ were observed in other samples. In a previous paper, ${ }^{18}$ it was reported that protein-like fluorophores released from phytoplankton consist of proteins with molecular weights of approximately 37 and $50-75 \mathrm{kDa}$. These results suggest that some of dissolved proteins in Lake Biwa might be mainly due to the production by phytoplankton.

The results of SDS-PAGE are consistent with the results of gel chromatography, as stated above. According to both results, the peaks at $\mathrm{RT}=20-22$ and $23-24 \mathrm{~min}$ detected by gel chromatography may correspond to the bands at $42-45$ and $33-35 \mathrm{kDa}$, respectively, detected by SDS-PAGE. The staining intensity of the band at $42 \mathrm{kDa}$ in the lake water sample collected in September 2014 was stronger than those collected in June and October 2014. Meanwhile, the fluorescence intensity of the peak ( $\mathrm{RT}=21-22 \mathrm{~min}$ ) in the water sample from September 2014 was higher than those in samples collected in June and October 2014, which was in agreement with the results of SDS-PAGE. However, the staining intensities of $56-59$ and $62-66 \mathrm{kDa}$, which might correspond to peaks at $\mathrm{RT}=17-20 \mathrm{~min}$, were not always consistent with the results of gel chromatography. This is probably because protein analysis using SDS-PAGE with silver staining is not quantitative. It is considered that a method with higher resolution than SDSPAGE is necessary to elucidate how many and what kinds of protein species exist in Lake Biwa and why they are stable. Then, 2-DE was applied for the protein analysis because 2-DE is a higher resolution technique than SDS-PAGE for separating individual proteins from a complex mixture of proteins. ${ }^{32}$

Analysis of concentrated protein-like fluorophores in Lake Biwa using 2-DE

In order to further elucidate the characteristics and dynamics of protein-like fluorophores in Lake Biwa, more concentrated protein-like fluorophores from a crossflow ultrafiltration system were analyzed using 2-DE. The 2-DE electrophoretograms of concentrated protein-like fluorophores in the surface water of Lake Biwa (St. 17B, water depth $0.5 \mathrm{~m}$ ) collected in February (30 L to $0.15 \mathrm{~mL})$, March $(20 \mathrm{~L}$ to $0.13 \mathrm{~mL})$, April $(10 \mathrm{~L}$ to $0.25 \mathrm{~mL}$ ), and June (10 L to $0.25 \mathrm{~mL}) 2017$ are shown in Fig. 4. The results of densitographic analysis from May 2016 to August 2017 are listed in Table 2. The molecular weight (MW) range of each sample in 2-DE was consistent with that determined in SDS-PAGE, but the number of protein spots increased compared with that of protein bands in SDS-PAGE. Many protein spots were detected in the isoelectric point $(\mathrm{p} I)$ range of 5.4-6.8 and the MW range of $30-80 \mathrm{kDa}$ on the 2-DE gels of the water sample collected in February 2017. The 30, 37, and $55 \mathrm{kDa}$ proteins were resolved into horizontally spread arrays (trains) of spots on the 2-DE gel, indicating that these proteins were a mixture of protein species having the same MW but different pIs. Yamada and Tanoue ${ }^{24,25}$ considered that the heterogeneity of the sugars would explain the difference in charges, because most of the dissolved proteins in seawater were glycosylated with different types of sugar chains. Therefore, these proteins in Lake Biwa might be glycosylated with a variable linkage between the sugar and polypeptide chains. The protein spots with $\mathrm{p} I \mathrm{~s}$ of $4.5-7.3$ and MWs of $29-95 \mathrm{kDa}$ were observed in the water sample collected in March 2017. Clear protein spots of $\mathrm{p} I \mathrm{~s} 5.2-6.8 / 71$ and $\mathrm{p} I$ 4.6/73 kDa were detected. Similar protein spots were observed in the samples collected in April 2017 (pI 4.5/76 kDa), June 2017 (pI 4.0/66, pIs 5.7 - 7.3/67 kDa), and August 2017 (pIs 5.4 - 6.1/70 kDa).

Furthermore, the results for Lake Biwa were compared with those for algal DOM released from phytoplankton during cultivation. Figure 5 shows the 2-DE electrophoretograms of concentrated protein-like fluorophores released from four kinds of phytoplankton, $M$. aeruginosa, $S$. dorsidentiferum, $F$. capucina, and $C$. ovata, during cultivation for 107, 161, 85, and 143 days, respectively. The results analyzed using NIH ImageJ are listed 

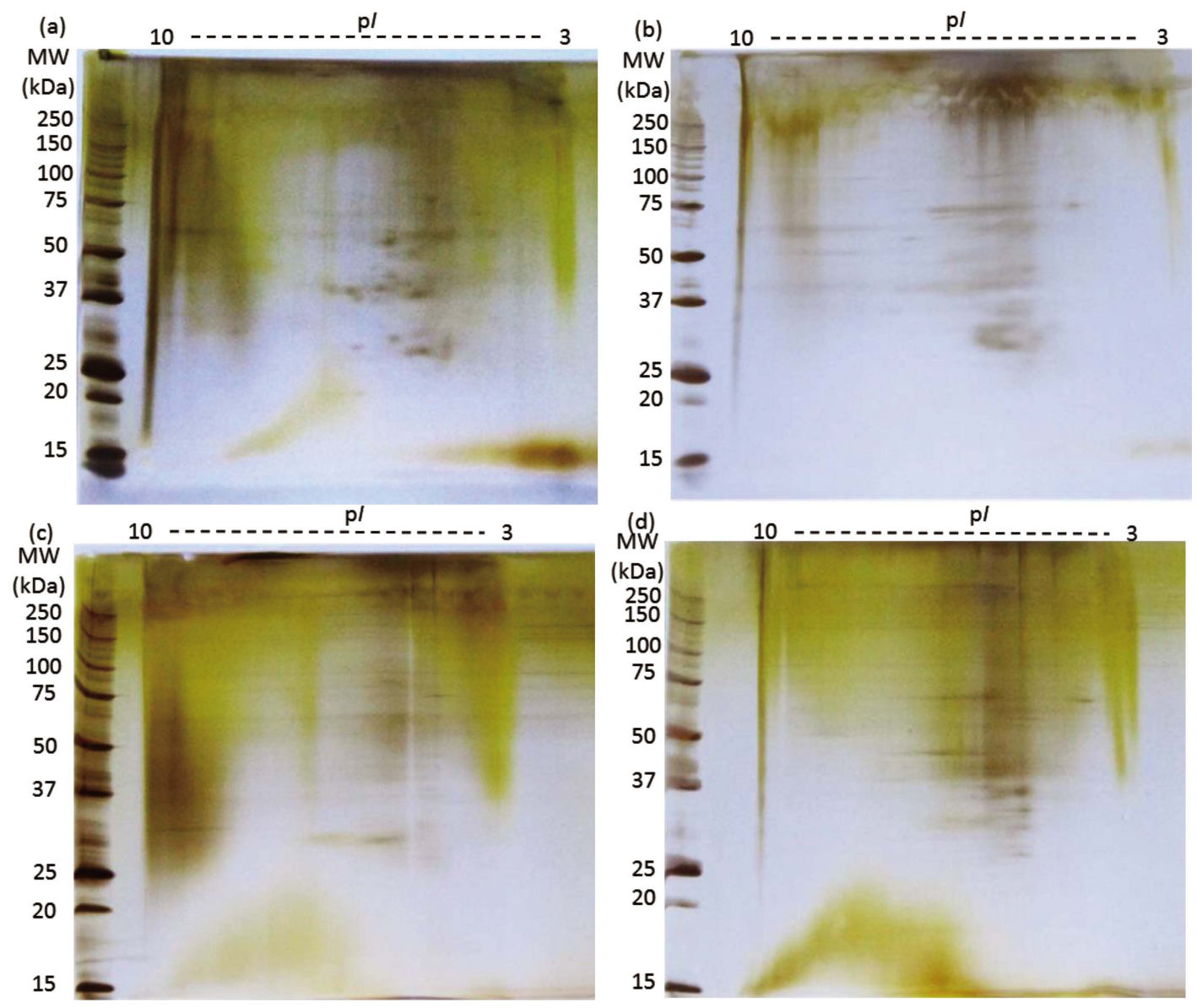

Fig. 4 2-DE electrophoretograms of the concentrated protein-like fluorophores in the surface water of Lake Biwa (St. 17B, water depth 0.5 m). (a) Feb. 2017, (b) Mar 2017, (c) Apr. 2017, (d) June 2017.

Table 2 Analytical results of $\mathrm{pI} / \mathrm{MW}(\mathrm{kDa})$ of protein-like fluorophores in the surface water samples of the northern basin of Lake Biwa (St. 17B, water depth $0.5 \mathrm{~m}$ ) using 2-DE

\begin{tabular}{|c|c|c|c|c|c|c|c|}
\hline \multirow{2}{*}{$\begin{array}{l}\mathrm{MW} / \\
\mathrm{kDa}\end{array}$} & \multicolumn{2}{|c|}{2016} & \multicolumn{5}{|c|}{2017} \\
\hline & May & November ${ }^{\mathrm{a}}$ & February & March & April & June & August \\
\hline $90-100$ & & & & $4.5 / 95$ & & & \\
\hline $75-90$ & & & $5.4 / 80$ & & $\begin{array}{l}5.3 / 88 \\
4.5 / 76\end{array}$ & & \\
\hline \multirow[t]{4}{*}{$50-75$} & $5.2-5.8 / 70$ & & & $4.6 / 73$ & & & $6.5 / 73$ \\
\hline & $\begin{array}{c}3.0 / 65 \\
4.0-4.8 / 64\end{array}$ & $6.0 / 68$ & & $5.2-6.8 / 71$ & & $\begin{array}{c}5.7-7.3 / 67 \\
4.0 / 66\end{array}$ & $5.4-6.1 / 70$ \\
\hline & $4.0 / 55$ & & $4.9-6.3 / 55$ & $7.3 / 58$ & & $5.1 / 58$ & \\
\hline & $5.0 / 53$ & $6.5 / 53$ & $5.7 / 50$ & & & $8.4-9.2 / 50$ & $6.0-7.1 / 54$ \\
\hline \multirow[t]{3}{*}{$40-50$} & $4.5 / 49$ & $6.5 / 44$ & & $6.1-6.7 / 48$ & & & \\
\hline & $4.5-5.0 / 45$ & $7.0 / 42$ & $6.1 / 43$ & $5.2-6.3 / 46$ & & $5.3-5.9 / 42$ & \\
\hline & $3.0 / 41$ & $6.5 / 40$ & $6.3 / 40$ & $5.2-6.4 / 41$ & & $5.1-5.8 / 40$ & \\
\hline \multirow[t]{4}{*}{$30-40$} & $3.5-4.5 / 39$ & & $6.8 / 39$ & & $4.7 / 39$ & & $5.0-6.1 / 37$ \\
\hline & $3.0 / 38$ & & $5.3-7.3 / 37$ & & $8.6-9.8 / 31$ & & $7.2 / 35$ \\
\hline & $4.0 / 36$ & & & $5.3-5.7 / 35$ & $5.1-5.8 / 30$ & $5.1 / 34$ & $5.5-6.6 / 33$ \\
\hline & & $7.0 / 31$ & $5.0-6.3 / 30$ & $5.7-6.2 / 32$ & $6.0-6.8 / 30$ & $5.1 / 31$ & \\
\hline \multirow{2}{*}{$20-30$} & & & & $5.5-6.1 / 29$ & & $5.3 / 28$ & \\
\hline & & & & & & $5.2 / 27$ & \\
\hline
\end{tabular}

a. Water depth $5 \mathrm{~m}$.

in Table 3. These results indicate that the 2-DE patterns of dissolved proteins in Lake Biwa were similar to those in algal DOM. For example, in the lake water sample collected in February 2017, the protein spots of pIs 5.0-6.3/30, pIs $6.1-$
$6.3 / 40$ - 43, and $\mathrm{p} I \mathrm{~s} 4.9-6.3 / 55 \mathrm{kDa}$ were similar to those of $\mathrm{p} I$ 6.7/31, $\mathrm{p} I \mathrm{~s}$ 6.1-7.0/37-46, and $\mathrm{p} I \mathrm{~s}$ 6.0-6.6/56 kDa, respectively, in $M$. aeruginosa. The protein spots of $\mathrm{p} I \mathrm{~s} 5.3-7.3 /$ $37-39 \mathrm{kDa}$ were similar to those of $\mathrm{p} I 6.5 / 36$ and $\mathrm{p} I \mathrm{~s} 5.6-6.7 /$ 

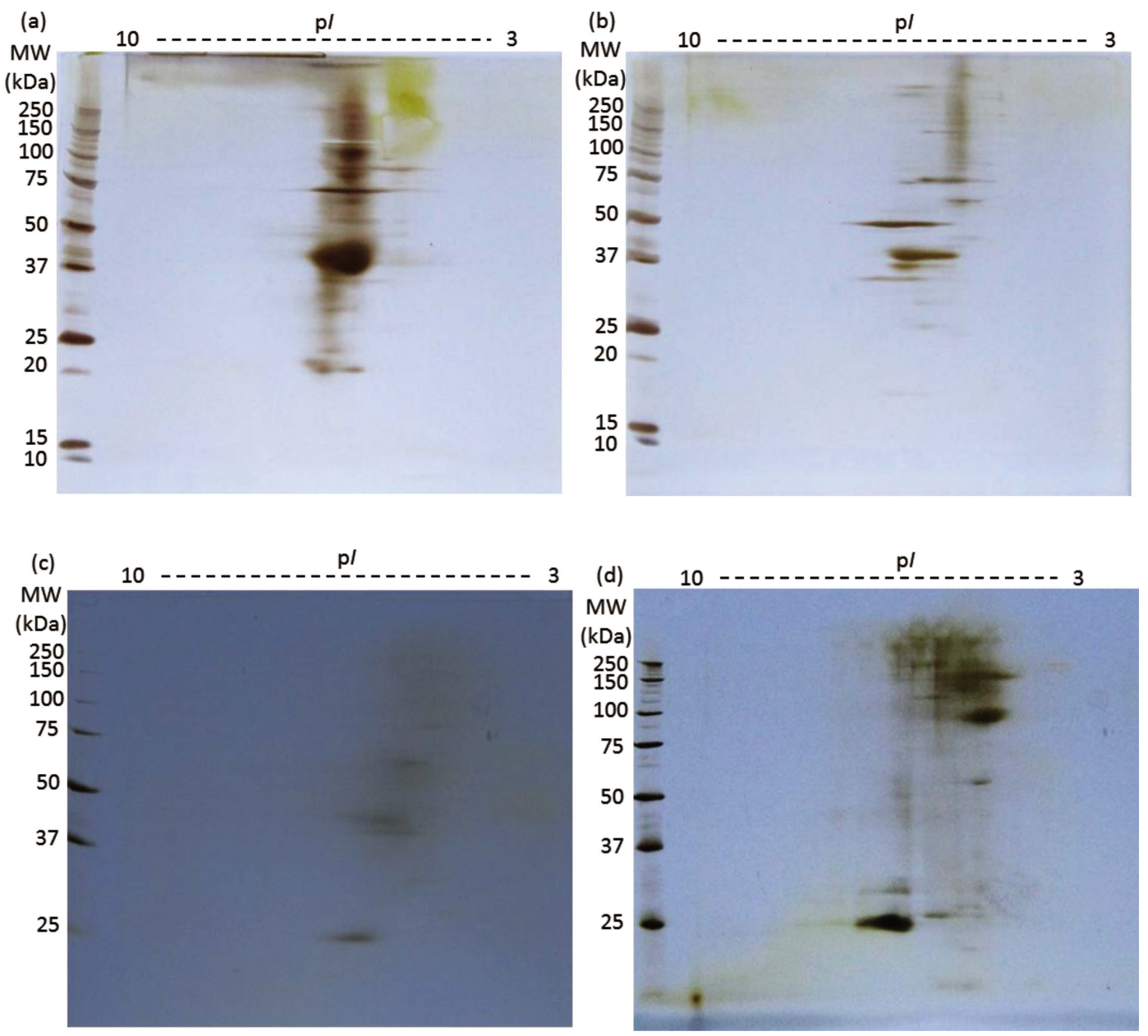

Fig. 5 2-DE electrophoretograms of the concentrated protein-like fluorophores from M. aeruginosa (a), S. dorsidentiferum (b), F. capucina (c), and C. ovata (d) during cultivation for 107, 161, 85, and 143 days, respectively.

Table 3 Analytical results of $\mathrm{pI} / \mathrm{MW}(\mathrm{kDa})$ of protein-like fluorophores released from four kinds of phytoplankton using 2-DE

\begin{tabular}{|c|c|c|c|c|}
\hline $\begin{array}{l}\mathrm{MW} / \\
\mathrm{kDa}\end{array}$ & M. aeruginosa & S. dorsidentiferum & F. capucina & C. ovata \\
\hline $90-100$ & $5.4-6.6 / 94$ & & & $4-5 / 95$ \\
\hline $75-90$ & $6.4 / 86$ & & $4.5 / 76$ & \\
\hline \multirow[t]{2}{*}{$50-75$} & $\begin{array}{c}5.8-7.0 / 73 \\
6.4 / 66\end{array}$ & $\begin{array}{c}5.4-6.2 / 72 \\
6.4 / 71\end{array}$ & & \\
\hline & $6.0-6.6 / 56$ & $5.5 / 61$ & $5 / 60$ & $4.5-5 / 55$ \\
\hline $40-50$ & $6.1-7.0 / 40-46$ & $5.8-7.3 / 48$ & $\begin{array}{c}6.5 / 42 \\
6 / 40\end{array}$ & \\
\hline $30-40$ & $6.1-7.0 / 37-39$ & $\begin{array}{c}5.6-6.7 / 38 \\
6.5 / 36\end{array}$ & & \\
\hline \multirow{3}{*}{$20-30$} & $6.7 / 31$ & $6.2-7.1 / 34$ & & $6-7 / 30$ \\
\hline & $6.7 / 24,27$ & & $6.5 / 24$ & $5-6 / 26$ \\
\hline & $6.3,6.9 / 21$ & & & $6-7 / 25$ \\
\hline
\end{tabular}

The days of cultivation of $M$. aeruginosa, $S$. dorsidentiferum, $F$. capucina and C. ovata were 107, 161,85 and 143 days, respectively.

$38 \mathrm{kDa}$ in $S$. dorsidentiferum. The protein spot of $\mathrm{p} I 6.3 / 40 \mathrm{kDa}$ was similar to that of $\mathrm{p} I 6 / 40 \mathrm{kDa}$ in $F$. capucina. In the water sample collected in April 2017, no spots similar to M. aeruginosa were detected, but the protein spots of $\mathrm{p} I \mathrm{~s}$ 6.0-6.8/30 and $\mathrm{p} I 4.5 / 76 \mathrm{kDa}$ similar to those of $\mathrm{p} I \mathrm{~s} 6-7 / 30 \mathrm{kDa}$ in $C$. ovata and $\mathrm{p} I 4.5 / 76 \mathrm{kDa}$ in $F$. capucina, respectively, were detected. The cell densities of Microcystis spp., Staurastrum spp. and Fragilaria spp in the plankton net sample collected in February 2017 were $8.55 \times 10^{5}, 2.48 \times 10^{4}$ and $3.4 \times 10^{3}$ cells $/ \mathrm{mL}$, respectively, and the ratio of cell densities of Microcystis spp. was $83.2 \%$. Meanwhile, the cell densities of Microcystis spp., Staurastrum spp. and Fragilaria spp in April 2017 were $4.27 \times 10^{4}, 1.08 \times 10^{4}$ and $4.82 \times 10^{4}$ cells $/ \mathrm{mL}$, respectively, and the ratio of cell densities of Microcystis spp. was 30.3\%. From these results, it is thought that the change in algal species may affect the changes in the electrophoretic gel images of lake water samples. These results also suggest that some of dissolved proteins in Lake Biwa are likely derived from phytoplankton. Therefore, it is necessary to clarify the relationship between the dynamics of source phytoplankton and the dissolved proteins in Lake Biwa. We are researching about the amino acid sequence of dissolved proteins in Lake Biwa using MALDI-TOF-MS and other techniques. ${ }^{33}$

\section{Acknowledgements}

We would like to thank Dr. K. Hayakawa, Mr. T. Okamoto, and the staff of Lake Biwa Environmental Research Institute for their kind cooperation in sampling. The present study was 
supported by Grants-in-Aid for Scientific Research from the Ministry of Education, Culture, Sports, Science and Technology (No. 23510006 and No. 26340050).

\section{References}

1. Shiga Prefecture, Kankyo Hakusyo, 2016.

2. A. Imai, NIES Research Booklet, 2004, 13, 12.

3. A. Imai, T. Fukushima, K. Matsushige, T. Inoue, and T. Ishibashi, Jpn. J. Limnol., 1998, 59, 53.

4. K. Amano, K. Matsumoto, A. Imai, and K. Matsushige, Jpn. J. Limnol., 2004, 27, 659.

5. C. Kim, Y. Nishimura, and T. Nagata, Limnol. Oceanogr., 2006, 51, 70 .

6. K. Maki, C. Kim, C. Yoshimizu, I. Tayasu, T. Miyajima, and T. Nagata, Limnology, 2010, 11, 143.

7. Y. Sato, T. Okamoto, K. Hayakawa, T. Okubo, and E. Komatsu, J. Japan Soc. on Water Environment, 2016, 39, 17.

8. E. M. Thurman, "Organic Geochemistry of Natural Waters", 1985, Martinus Nijhoff/Dr. W. Junk Publishers, Dordrecht.

9. S. Ichise, H. Ikegaya, S. Furuta, N. Fujiwara, S. Ikeda, N. Kishimoto, and O. Nishimura, Jpn. J. Water Treat. Biol., 2013, 49, 65.

10. S. Aoki, Y. Fuse, and E. Yamada, Anal. Sci., 2004, 20, 159.

11. S. Aoki, S. Ohara, K. Kimura, H. Mizuguchi, Y. Fuse, and E. Yamada, Anal. Sci., 2008, 24, 389.

12. S. Aoki, S. Ohara, K. Kimura, H. Mizuguchi, Y. Fuse, and E. Yamada, Anal. Sci., 2008, 24, 1461.

13. S. Ohara, T. Uehara, K. Kimura, T. Yoshida, S. Fujiwara, H. Mizuguchi, Y. Fuse, and E. Yamada, Bunseki Kagaku, 2009, 58, 231.

14. H. Mizuguchi, Sou Fujii, Shiori Fujii, R. Higa, K. Ishikawa, K. Hayakawa, T. Okamoto, Y. Fuse, H. Karatani, and E.
Yamada, Limnological Study, 2018, 5, 3.

15. E. Yamada, S. Ohara, T. Uehara, T. Hirota, N. Hatori, Y. Fuse, and S. Aoki, Anal. Sci., 2012, 28, 675.

16. E. Yamada, T. Ueda, T. Tanaka, K. Fujii, H. Mizuguchi, and Y. Fuse, J. Environment and Safety, 2018, 9, 23.

17. P. G. Coble, Mar. Chem., 1996, 51, 325.

18. E. Yamada, T. Hirota, N. Hatori, Y. Kitao, Y. Fuse, S. Aoki, H. Karatani, and T. Matsunaga, Anal. Sci., 2012, 28, 595.

19. E. R. M. Druffel, P. M. Williams, J. E. Bauer, and J. R. Ertel, J. Geophys. Res. 1992, 97, 15639.

20. H. Ogawa, Y. Amagi, I. Koike, K. Kaiser, and R. Benner, Science, 2001, 292, 917.

21. H. Ogawa and E. Tanoue, J. Oceanogr., 2003, 59, 129.

22. E. Tanoue, Mar. Chem., 1995, 51, 239.

23. N. Yamada, S. Suzuki, and E. Tanoue, J. Oceanogr., 2000, 56,583

24. N. Yamada and E. Tanoue, Limnol. Oceanogr., 2003, 48, 1037.

25. N. Yamada and E. Tanoue, Prog. Oceanogr., 2006, 69, 1.

26. N. Yamada and E. Tanoue, J. Oceanogr., 2009, 65, 223.

27. M. J. Powell, J. N. Sutton, C. E. Del Castilloa, and A. T. Timperman, Mar. Chem., 2005, 95, 183.

28. E. Yamada, K. Doi, K. Okano, and Y. Fuse, Anal. Sci., 2000, 16, 125.

29. H. Hirano, "Proteome Kaiseki (Proteome Analysis, in Japanese)", 2001, Tokyokagakudojin, Tokyo, 15.

30. C. A. Schneider, W. S. Rasband, and K. W. Eliceiri, Nature Methods, 2012, 9, 671.

31. W. Rasband, National Institute of Health, USA, Image Processing and Analysis in Java, https://imagej.nih.gov/ij/.

32. P. H. O'Farrell, J. Biol. Chem., 1975, 250, 4007.

33. R. Higa, H. Mizuguchi, S. Fujii, K. Fujii, Y. Fuse, H. Karatani, E. Yamada, T. Okamoto, and K. Hayakawa, Abstracts of 83rd Conference of the Japanese Society of Limnology, 2018, 63. 